\title{
Apresentação ao Número 32
}

\author{
Mariângela de Araújo* \\ Álvaro Faleiros \\ Elena Vássina*
}

Neste número de nossa revista temos a oportunidade de constatar, uma vez mais, a riqueza e diversidade dos estudos de tradução e de terminologia no Brasil. Chama logo a atenção o fato de haver pesquisadores do Rio Grande do Sul à Paraíba, passando por Minas Gerais, Brasília e São Paulo, estando, desse modo, praticamente todas as regiões do Brasil aqui presentes. A diversidade se deve também ao fato de os assuntos variarem desde a interpretação assistida por computadores até a antropologia, passando pela avaliação e pelo diagnóstico na área de fonoaudiologia, pelo licenciamento ambiental, pelas competências tradutórias do tradutor público e do intérprete comercial, pela tradução de games, prova de que estamos superando a centralidade da tradução literária nos estudos da tradução no Brasil.

Assim, no estudo que abre este número, “Ferramentas de Interpretação Assistida por Computador (CAl) e opções de automação com o Reconhecimento Automático de Fala", o engenheiro Luís Eduardo Schild Ortiz e a tradutora e intérprete Patrizia Cavallo partem da constatação de que diversos estudos nos últimos anos apontam a resistência de intérpretes à adoção de novas tecnologias, mesmo se essas permitiram o desenvolvimento de ferramentas para auxiliar esses profissionais. Para atualizar o pesquisador brasileiro sobre essas ferramentas, os autores se fazem revisão de literatura e de pesquisa documental com o intuito de verificar quais delas permanecem sendo atualizadas e disponíveis no mercado. Em seguida, são apresentados os conceitos de automação e de uso de reconhecimento automático de fala (ASR), para, por meio da análise de seus potenciais benefícios, apresentar uma visão do estado da arte da tecnologia para interpretação, assim como algumas perspectivas futuras nessa área.

\footnotetext{
* Docente do Departamento de Letras Clássicas e Vernáculas da Faculdade de Filosofia, Letras e Ciências Humanas da USP.

** Docente do Departamento de Letras Modernas da Faculdade de Filosofia, Letras e Ciências Humanas da USP.

*** Docente do Departamento de Letras Orientais da Faculdade de Filosofia, Letras e Ciências Humanas da USP.
} 
Em “Tradução e adaptação transcultural de instrumentos de avaliação em Fonoaudiologia para o português brasileiro: uma análise das diretrizes" a pesquisadora em fonoaudiologia Nayara Ribeiro da Silva e a doutora em ciências Leila Maria Gumushian Felipini, após constatar que, no Brasil, há escassez de instrumentos formais e objetivos comercialmente disponíveis em português e indicados para avaliação e diagnóstico na área de Fonoaudiologia, apontam que uma das formas encontradas para amenizar esse problema é traduzir instrumentos já disponíveis em outras línguas. As pesquisadoras destacam ainda que, mesmo se historicamente, a adaptação de instrumentos elaborados em outra cultura se detinha na simples tradução do original, estudiosos de diferentes áreas temáticas vêm sugerindo que a avaliação semântica seja apenas um dos passos necessários ao processo de adaptação transcultural. Nesse sentido, são propostos na literatura alguns conjuntos de instruções padronizadas e diretrizes específicas para a tradução e a adaptação transcultural de instrumentos. Partindo dessas premissas, o estudo apresenta aqui as diretrizes recorrentes em estudos que executam a tradução e a adaptação transcultural de instrumentos a partir de artigos científicos indexados em bases de dados nacionais e internacionais que descrevem esse processo em suas metodologias.

A analista de Meio Ambiente da Secretaria de Estado de Meio Ambiente de Mato Grosso, Caroline Lúcia Costa Moia Chichorro, conjuntamente com a Professora do Departamento de Línguas Modernas da Universidade Federal do Rio Grande do Sul (UFRGS), Patrícia Chittoni Ramos Reuillard, repertoriam, no artigo “Terminologia do Licenciamento Ambiental Brasileiro em Português e Inglês" os termos do licenciamento ambiental brasileiro, oferecendo seus equivalentes em língua inglesa. Para tal foram utilizados dois corpora, nos idiomas português e inglês, estudados com base nos pressupostos da Teoria Comunicativa da Terminologia, da Linguística de Corpus e no conceito de equivalência funcional. Os corpora foram analisados com o programa AntConc (ANTHONY 2014), com apoio da árvore de domínio e dos fluxogramas do licenciamento ambiental elaborados. Foram validados 371 termos do domínio do licenciamento ambiental. Dadas as diferenças jurídicas e culturais existentes entre as línguas selecionadas, evidenciadas na terminologia estudada, observou-se não ser possível oferecer um equivalente funcional para todos os termos repertoriados, reforçando a necessidade em prosseguir com a pesquisa.

A professora Leila Maria Gumushian Felipini é também co-autora de um segundo artigo, desta vez com Jonatã José Roberto Cardoso Nanetti. Intitulado “O perfil do 
Tradutor Público e Intérprete Comercial: um estudo sobre competências tradutórias”, o trabalho apresenta uma reflexão sobre a profissão de Tradutor Público e Intérprete Comercial com o intuito de estabelecer um perfil recomendado aos Tradutores Públicos e Intérpretes Comerciais, por meio de levantamento bibliográfico, documental e exploratório. Utilizando referências como Francis Aubert, Stella Tagnin, Adriana Pagano e Fábio Alves, os autores chegam à conclusão de que a formação formal fornece ao tradutor a otimização das subcompetências tradutórias responsáveis pelo bom desenvolvimento profissional, ainda que, como assinalam os pesquisadores, a maioria dos tradutores em atuação hoje em dia não possua tal formação.

“A Localização em jogo na tradução de games”, de Gleiton Malta e de Luiz Gustavo Nogueira Barcelo, se debruça sobre um dos temas mais atuais dos estudos da tradução, a localização. Esse estudo analisa mais precisamente a tradução das falas (dublagem e legenda) do jogo Overwatch, buscando traços de localização. Nele, os autores comparam a tradução do texto fonte em inglês para o espanhol e para o português do Brasil. Para tal, o material linguístico do jogo foi extraído nos três idiomas e transcrito. Ao longo do estudo, os dados revelam que o corpus em inglês é maior e mais rico lexicalmente que os subcorpora do português e do espanhol, bem como a versão brasileira é maior e mais rica lexicalmente que a versão em espanhol. Tal análise permitiu aos autores comprovar que a versão brasileira localiza mais o conteúdo linguístico que a versão em espanhol.

0 artigo seguinte, “A retextualização interlinguística de fábulas: um estudo de caso”, escrito pelas pesquisadoras Clarissa Rosas e Heloísa Pezza Cintrão, é na verdade parte de uma pesquisa maior. Nele, as autoras se debruçam sobre uma fábula do espanhol Tomás de Iriarte, publicada em 1782 e traduzida à língua portuguesa em diferentes momentos ao longo dos séculos XVIII e XX. O texto começa tratando da formação do conceito de literatura infantil e da evolução histórica desse gênero, chegando à inserção da fábula na literatura infantil. A partir desse quadro, apresenta o modelo descritivo de tradução proposto por Lambert e Van Gorp e o trabalho de Genette acerca dos paratextos editoriais, com vistas a esquematizar alguns pontos para análise, para, por fim, propor análise de duas retextualizações interlinguísticas (espanholportuguês) da fábula “El Pato y la Serpiente” em relação a seu texto-fonte.

“Imagens de um certo Brasil e redes de significância na tradução para o português de Là où les tigres sont chez eux, de Jean-Marie Blas de Roblès: emergência do exótico?", de Raquel Peixoto do Amaral Camargo, se debruça sobre imagens do Brasil e 
redes de significância que aparecem no romance Là où les tigres sont chez eux, de JeanMarie Blas de Roblès. Ao longo do texto são observadas refrações na tradução para o português feita por Mauro Pinheiro e Maria de Fátima do Coutto. Com o objetivo de perceber como se dá a criação de um Brasil exótico no romance e de como esse exótico emerge e se reconfigura na tradução, a autora observa o processo criativo do autor que, mediante um movimento de reversão de expectativas, engendra a construção de redes de significância e de imagens do Brasil. Em seguida, são analisadas diferenças que reiteram ou enfraquecem as redes de significância do original, e daí são tiradas algumas consequências advindas das diferenças encontradas.

Encerra o número, com chave de ouro, a entrevista do professor titular da USP, John Milton, concedida a Telma Franco. Nela, o entrevistado retoma boa parte de sua trajetória, com destaque para as décadas de trabalho na USP, durante as quais participou ativamente para a consolidação da tradução como campo de estudo no Brasil e no exterior. 